\title{
Executive Unconscious-Bias and Employee Job Satisfaction in Government Parastatals in Lagos State Nigeria
}

\section{Fatunmbi Oladotun Muideen*}

Administrative Staff College of Nigeria, Topo-Badagry, Lagos, Nigeria

*Corresponding author: Muideen FO, Administrative Staff College of Nigeria, Topo-Badagry, Lagos, Nigeria, Tel: +234 8164824000 ; E-mail: mdotfat@yahoo.com

Received date: January 05, 2018; Accepted date: February 25, 2018; Published date: March 05, 2018

Copyright: @ 2018 Muideen FO. This is an open-access article distributed under the terms of the Creative Commons Attribution License, which permits unrestricted use, distribution, and reproduction in any medium, provided the original author and source are credited.

\begin{abstract}
The study investigates executive unconscious-bias and job satisfaction in government parastatals in Lagos State, Nigeria. The descriptive survey research design was adopted while the simple random sampling technique was used to draw 120 sample respondents. Questionnaire rated on a 6-point Likert scale, was the main instrument for data collection, 120 copies of questionnaire. The descriptive statistical techniques of Percentiles and Pearson Correlation were used for data analysis with the aid of Statistical Package for Social Sciences (SPSS) software for editing and encoding. The result reveals that there is a weak negative relationship between executive-unconscious and job satisfaction among employees of the selected parastatals in the state $(R=-0.193, p<0.05)$. The study recommends that it is imperative for executives to examine themselves and be self-aware of their unconscious biases so they can consciously work on them.
\end{abstract}

Keywords Executive unconscious-bias; Job satisfaction; Government parastatals

\section{Introduction}

Unconscious bias has been shown to affect the ways managers deliver their duties in organizations, from decision making to communication and quality of support and supervision given to employees. Kyko [1] identified among other factors, biased boss as a factor contributing to a toxic work environment which in turn leads to low productivity of workers. Nwagboso et al. [2] found that there is a significant relationship between employee job satisfaction and leadership behavior. Also, research has confirmed the impact of levels of relationship with immediate supervisor and level of relationship with co-workers on job satisfaction.

The strategic role of leadership to achieving employee job satisfaction and sustain performance has been emphasized by many researchers. However, not much has been done to investigate the effect of implicit bias on leadership behavior and its impact on job satisfaction and employee performance, most especially in Nigeria. Therefore, the existence of implicit bias in an organization, which could affect leadership behavior, with inferred impact on job satisfaction and employee performance needs to be investigated.

Leaders without the right attitude and behavior will find it extremely difficult to positively influence their employees, who are more than critical resources but partners in the achievement of the organization's goals and objectives. The business environment is changing as a result of many societal forces. The issues of globalization, diversity and inclusion are creating very dynamic and culturally diverse organizations that require unbiased leaders to successfully manage. Many factors influence the performance of an organization, and there is little doubt that the quality of leadership is one of the most critical determinants of organizational success [3]. Leadership behavior plays a very important role in enhancing employee job satisfaction, work motivation and work performance [3]. Good leadership behavior accelerates the development of most organizations.

\section{Statement of problem}

Leadership behavior affects how satisfied the employees would be, which can in turn affect how well they perform on their job. Different researches have been carried out to show the effect of leadership on job satisfaction and employee productivity. Leadership styles have been noted among other factors, as a critical variable responsible for employee job satisfaction and performance [4-9]. Employee job satisfaction is influenced by the internal organization environment which includes organizational climate, leadership styles and personnel relationship [10-14]. The quality of the leader-employee relationship or the lack thereof - has a great influence on the employee's self-esteem and job satisfaction [15-20]. Negative leader-employee relations reduce productivity and increase absenteeism and the turnover to the organization can be quite high [21-23].

\section{Objective of the study}

The objective of the research is to investigate the effect of executiveunconscious bias on employee job satisfaction in government parastatals in Lagos State, Nigeria.

\section{Research questions}

How does executive unconscious-bias affect employee job satisfaction in government parastatals in Lagos State, Nigeria?

\section{Research hypothesis}

$\mathrm{H}_{\mathrm{o}}$ : Executive unconscious-bias has no significant effect on employee job satisfaction in government parastatals in Lagos state, Nigeria. 
Page 2 of 4

\section{Significance of the study}

Leadership has been identified as one of the main factors affecting productivity in every work organization [24]. Therefore, to enhance employee work performance and organizational effectiveness, the issue of unconscious biases must be taken very seriously [25].

Employee's effectiveness is increased on the job when he gets personal attention and strong response from the supervisor. Supervisor's and manager's role is important in uplifting the performance of employees at work [26-33].

\section{Literature Review}

Nwachukwu [13] identified supervision, subordinates, the environment and outcome as the major variables that influence productivity. Productivity is rarely measured directly but inferred from changes in employee's attitude and behavior such as organizational commitment, organizational citizenship behavior and job satisfaction [34-45].

The fundamental factors influencing the effectiveness of an organization are leadership and job satisfaction [46-50]. Leadership is considered to be one of the most important determinants of employee's job satisfaction. It extensively influences employee's motivation and dedication.

There is a significant relationship between employee job satisfaction and leadership behavior [51]. They investigated the relationship between leadership behavior (independent variable) and employee job satisfaction (dependent variable) among selected paramilitary workers in Benin City, Edo Sate. It was found that noticeable leadership behaviors were transformational and transactional and the employees were to an average extent satisfied with their work [52-55].
Pandita and Domnic [14] reviewed various variables affecting job satisfaction and job dissatisfaction. Supervision was identified as one of the variables. According to their study, supervision plays a very important role in evaluating and enhancing the performance of each individual employee [56-60]. A supervisor or leader by all means has to be neutral and his/her individual preferences should never come into deciding or evaluating the performance of an individual. House et al. [15] also observed that subordinates reflect a greater amount of job satisfaction for having leaders or supervisors, who are high on consideration [31-65].

\section{Methodology}

The descriptive survey research design was adopted for the study. 120 respondents were randomly selected from some government parastatals in Lagos State, Nigeria. A structured questionnaire, divided into two parts $\mathrm{A}$ and $\mathrm{B}$, was used in collecting the required data from the respondents. Part A contained items on the demographic variables and Part B contained items to measure the active variables of Executive unconscious-bias and Job satisfaction. The questionnaire was rated on a six-point Likert Scale from Strongly Agree to Strongly Disagree while the descriptive statistical techniques of Simple Percentile and Regression Analysis were used to analyse the data.

\section{Results and Analysis}

H0: There is no significant relationship between leader-unconscious bias and employee job satisfaction.

LUB-Leader-Unconscious Bias

JS-Job Satisfaction.

\begin{tabular}{|l|l|l|l|l|}
\hline Model & $\mathbf{R}$ & $\mathbf{R}$ Square & Adjusted R Square & Std. Error of the Estimate \\
\hline 1 & $-.193^{\mathrm{a}}$ & 0.037 & 0.026 & 16.789 \\
\hline \multicolumn{2}{|l}{} \\
\hline
\end{tabular}

Table 1: Model summary.

The model summary table shows that there is a very weak negative relationship between leader-unconscious bias and job satisfaction among staff of the institution with regression coefficient of -0.193 and the adjusted R-square of 0.026 . The result also revealed that only $3.7 \%$ variation in job satisfaction can be explained by leader-unconscious bias (Table 1).

\begin{tabular}{|c|c|c|c|c|c|}
\hline ANOVA ${ }^{a}$ Model & Sum of Squares & Df & Mean Square & $\mathbf{F}$ & Sig. \\
\hline Regression & 956.316 & 1 & 956.316 & 3.393 & $.042^{b}$ \\
\hline Residual & 24805.34 & 88 & 281.879 & & \\
\hline Total & 25761.66 & 89 & & & \\
\hline
\end{tabular}

Table 2: ANOVA model.

The ANOVA table indicates F-value of 3.393 and p-value of 0.042 . This implies that the test is significant, that is the model is adequate and sufficient in relating job satisfaction and leader-unconscious bias (Table 2). 


\begin{tabular}{|c|c|c|c|c|c|}
\hline \multirow[b]{2}{*}{ Coefficients ${ }^{a}$ Model } & \multicolumn{2}{|c|}{ Unstandardized Coefficients } & \multirow{2}{*}{$\begin{array}{l}\text { Standardized Coefficients } \\
\text { Beta }\end{array}$} & \multirow[t]{2}{*}{$\mathbf{T}$} & \multirow[b]{2}{*}{ Sig. } \\
\hline & B & Std. Error & & & \\
\hline (Constant) & 52.121 & 5.482 & & 9.507 & 0 \\
\hline LUB & -0.233 & -0.126 & -0.193 & -1.842 & 0.042 \\
\hline
\end{tabular}

Table 3: The model is coefficient model.

\section{$\mathrm{JS}=52.121-0.233 \mathrm{LUB}$.}

The hypothesis is significant because the p-value of 0.042 is less than the significance value of 0.05 , hence the alternative hypothesis is accepted and we then conclude that leader-unconscious bias has significant relationship with job satisfaction. The leadershipunconscious bias contributes negatively to job satisfaction among staff of the institution (Table 3).

\section{Conclusion}

Unconscious biases have been shown to influence virtually everything in the work place, from decision making, to recruitment and selection, promotion, compensation and benefits, training and development, and termination.

Unconscious biases affect the quality of supervision by the leaders in work organizations resulting in negative consequences on the employee performance. It is therefore imperative that managers and leaders take without levity the issues of unconscious biases as it affects the employees' tasks accomplishment and employees' job satisfaction in order to heighten the level of output and their general performance. People and institutions not only have a moral responsibility for their implicit bias, but a business responsibility; institutions need to be efficient and effective, and decisions and actions need to be taken based on evidence and fact, rather than stereotypes and hunches. Therefore, it is imperative for leaders to examine themselves and be self-aware of their unconscious biases so they can consciously work on them.

\section{References}

1. Kyko OC (2005) Instrumentation: Know Yourself and others. New York: Longman.

2. Nwagboso IR, Onuoha BC, Akhige JO (2016) Leadership Behaviour and Employee Job Satisfaction Among Paramilitary Workers in Benin City, Edo State. International Journal of Advanced Academic Research/Social \& Management Sciences 2: 17-33.

3. Ali ASA, Elmi HO, Mohamed AI (2013) The effect of leadership behaviour on staff performance in Somalia. Educational Research International 2: 196-210.

4. Frazier DWP (2005) Job satisfaction of international educators. United State: Universal-Publishers.

5. Bruce WM, Blackburn JW (1992) Balancing Job Satisfaction and Performance. Westport, CT: Quorum Books.

6. Agyen-Gyasi K (2013) Policy Implications of Staff Turnover at the Kwame Nkrumah University of Science and Technology Library. Journal of Science and Technology 33: 88-103.

7. Gibson JL, Ivancevich JM, Donnelly JH, Konopaske R (1991) Organization: Behaviour, Structure, Processes. New York: McGraw Hill.
8. Haenisch JP (2012) Factors Affecting the productivity of government workers. Gender Studies Journals.

9. Segun-Adeniran CD (2015) Leadership Styles and Job Productivity of University Library Staff: Interrogating the Nexus. Library Philosophy and Practice.

10. Seashore SE, Taber TD (1975) Job satisfaction and their correlations. American Behaviour and Scientists.

11. DeCremer D (2003) Why inconsistent leadership is regarded as procedurally unfair: The importance of social self-esteem concerns. European Journal of Social Psychology 33: 535-550.

12. Okafor EE (2013) Leadership and productivity in Nigeria: Implications for work organizations and national development. Journal of Research in National Development.

13. Nwachukwu CC (1987) Management Theory and Practice. Onitsha: Afircana FEB Publisher Limited.

14. Pandita R, Domnic J (2016) Variables of Job Satisfaction: A Review study with special reference to LIS Professionals. International Journal of Information Dissemination and Technology 6: 258-267.

15. House RJ, Filley AC, Kerr S (1971) Relationship of Leader Consideration and Initiating structure to $\mathrm{R}$ and $\mathrm{D}$ subordinate's satisfaction. Administrative Science Quarterly 16: 19-30.

16. Herbert C (2013) Unconscious bias and Higher education. Equality Challenge Unit.

17. Agbonifoh BA, Agbadudu AB, Iyayi FIO (2005) Management: A Nigerian Perspective. Lagos: Malthouse Press Limited.

18. Armstrong M (2006) A Handbook of Human Resource Management Practice (10th edn.), London, Kogan Page.

19. Beattie G, Cohen D, McGuire L (2013) An Exploration of Possible Unconscious Ethnic Biases in Higher Education: The Role of Implicit Attitudes on Selection for University Posts. Semiotica 197: 171-201.

20. Blair IV (2002) The Malleability of Automatic Stereotypes and Prejudice. Personality and Social Psychology Review 6: 242-261.

21. Burgess S, Greaves E (2009) Test Scores, Subjective Assessment and Stereotyping of Ethnic Minorities. University of Bristol.

22. Business Terms Glossary

23. Dasgupta N (2013) Implicit Attitudes and Beliefs Adapt to Situations: A Decade of Research on the Malleability of Implicit Prejudice, Stereotypes, and the Self-Concept. Advances in Experimental Social Psychology 47: 233-279.

24. Ellickson MC, Logsdon K (2002) Determinants of Job satisfaction of Municipal government employee. Public Personnel Management 31: 343-358.

25. Dansereau F, Alutto JA, Markham SE, Dumas MD (1982) Multi-Plexed Supervision and Leadership: An Application of Within and Between Analysis, In: Hunt JG, Sekaran U, Schriesheim CA (Eds.), Southern Illinois University Press, Carbondale, pp: 81-103.

26. Luthans F, Luthans BC, Luthans KW (2015) Organizational Behaviour: An Evidence-Based Approach. McGraw Hill Irwin, pp: 413-434.

27. Gaddis SM (2014) Discrimination in the Credential Society: An Audit Study of Race and College Selectivity in the Labour Market. Soc Forces 93: 1451-1479. 
Citation: Muideen FO (2018) Executive Unconscious-Bias and Employee Job Satisfaction in Government Parastatals in Lagos State Nigeria.

28. Graves LM, Powell GN (1995) The effect of sex similarity on recruiters' evaluation of actual applicants: A Test of the Similarity Attraction Paradigm. Personal Psychology 48: 85-98.

29. Greenwald AG, Krieger LH (2006) Implicit Bias: Scientific Foundations. California Law Review 94: 945-967.

30. Greenwald AG, Banaji MR, Rudman LA, Farnham SD, Nosek BA et al., (2002) A Unified Theory of Implicit Attitudes, Stereotypes, Self-Esteem, and Self-Concept. Psychological Review 109: 3-25.

31. Anthony GG, Andrew PT, Luis UE, Mahzarin BR (2009) Understanding and using the implicit association tests: III. Meta-analysis of predictive validity. Journal of Personality and Social Psychology 97: 17-41.

32. Guynn J (2015) Google's "bias busting" workshops target hidden prejudices. USA Today.

33. Henneman T (2014) You, biased? No, it's your brain. Workforce.

34. Hogan J, Hogan R (2002) Leadership and Sociopolitical Intelligence. Multiple intelligences and leadership, pp: 75-88.

35. Hong LC, Abl Hamid NIN, Salleh NM (2013) A study on the factors affecting job satisfaction among employees of a factory in Seremban Malaysia. Business Management Dynamics 3: 26-40.

36. McCormick H (2015) The Real Effect of Unconscious Bias in the Workplace. UNC Executive Development.

37. Iqbal N, Anwar S, Haider N (2015) Effect of Leadership style on Employee Performance. Arabian J Bus Manag Review 5: 146.

38. Moody JA (2010) Rising Above Cognitive Errors: Improving Searches, Evaluations, and Decision Making.

39. Jost JT, Rudman LA, Blair IV, Carney DR, Dasgupta N, et al., (2009) The Existence of implicit bias is beyond reasonable doubt: A refutation of ideological and methodological objections and executive summary of ten studies that no manager should ignore. Research in Organizational Behaviour 29: 39-69.

40. Kandola B (2010) The Value of difference: eliminating bias in organizations. Oxford: Pearn Kandola.

41. Kang J (2005) Trojan Horses of Race. Harvard Law Review 118: 1489-1593.

42. Kang J (2009) Implicit Bias: A Primer for the Courts: Prepared for the National Campaign to Ensure the Racial and Ethnic Fairness of America's State Courts.

43. Levinson JD, Smith RJ (2012) Implicit Racial Bias Across the Law. Cambridge, MA: Cambridge University Press, pp: 132-145.

44. Kang J, Bennett M, Carbado D, Casey P, Dasgupta N, et al., (2012) Implicit Bias in the Courtroom. UCLA Law Review 59: 1124-1186.

45. Komal KB, Tahir MQ (2007) Impact of Employee Participation on Job Satisfaction, Employee Commitment and Employee Productivity. International Review of Business Research Papers 3: 54-68.

46. Liao H, Chang A (2004) A Multilevel investigation of factors influencing employee service performance and customer outcomes. Academy of Management Journal 47: 41-58.
47. Long CP, Bendersky C, Morril C (2011) Fairness Monitoring: Linking Managerial Controls and fairness judgments in organization. Academy of Management Journal 54: 1045-1068.

48. Brainard M (2016) Leadership Pitfalls and Insights into Unconscious Bias.

49. Nosek BA, Smyth FL, Hansen JJ, Devos T, Linder NM, et al., (2007) Pervasiveness and Correlates of Implicit Attitudes and Stereotypes. European Review of Social Psychology 18: 36-88.

50. Phillips JJ, Connel AO (2003) Managing employee retention: a strategic accountability approach. USA: Butterworth-Heinemann.

51. Rachlinski JJ, Johnson SL, Wistrich AJ, Guthrie C (2009) Does Unconscious Racial Bias Affect Trial Judges? Notre Dame Law Review 84: 1195-1246.

52. Rashid S, Shireen M, Rab NL, Anam I, Hafiza HN, et al., (2013) Factors affecting the performance of employees at work place in the banking sector of Pakistan. Middle-East Journal of Scientific Research 17: 1200-1208.

53. Reskin B (2005) Unconsciousness Raising. Regional Review 14: 32-37.

54. Roberson L, Deitch EA, Brief AP, Block CJ (2003) Stereotype Threat and Feedback Seeking in the Workplace. Journal of Vocational Behavior 62: 176-188.

55. Rooth DO (2007) Implicit Discrimination in Hiring: Real World Evidence.

56. Ross H (2008a) Proven Strategies for Addressing Unconscious Bias in the Workplace. New York, NY: Diversity Best Practices.

57. Ross H (2008b) Exploring unconscious bias. Diversity Best Practices.

58. Rudman LA (2004) Social Justice in Our Minds, Homes, and Society: The Nature, Causes, and Consequences of Implicit Bias. Social Justice Research 17: 129-142.

59. Smith PC, Kendall LM, Hulin CL (1969) The measurement of satisfaction in work and retirement : A Strategy for the Study of Attitudes. Rand McNally, Chicago.

60. The impact of unconscious bias.

61. Tinkler JE (2012) Controversies in Implicit Race Bias Research. Sociology Compass 6: 987-997.

62. Davi W (2017) Why Great Leaders Must Acknowledge Implicit Bias.

63. Wilkie D (2014) Rooting out hidden bias. SHRM.

64. Wood M, Hales J, Purdon S, Sejersen T, Hayllar O (2009) A Test for racial discrimination in recruitment practice in Bristish cities. London: National Centre for Social Research for the Department of work and Pensions.

65. Ziegert JC, Hanges PJ (2005) Employment Discrimination: The Role of Implicit Attitudes, Motivation, and a Climate for Racial Bias. Journal of Applied Psychology 90: 553-562. 